\title{
Geo-Chip analysis reveals reduced functional diversity of the bacterial community at a dumping site for dredged Elbe sediment
}

\author{
Rebecca Störmer*, Antje Wichels, Gunnar Gerdts \\ Microbial Ecology Group Alfred Wegener, Institute for Polar and Marine Research, Kurpromenade 201, 27498 Helgoland, Germany
}

\section{A R T I C L E I N F O}

\section{Keywords:}

Dredged sediment

Pollution

Multivariate statistics

Functional gene arrays

Bacterial community

\begin{abstract}
A B S T R A C T
The dumping of dredged sediments represents a major stressor for coastal ecosystems. The impact on the ecosystem function is determined by its complexity not easy to assess. In the present study, we evaluated the potential of bacterial community analyses to act as ecological indicators in environmental monitoring programmes. We investigated the functional structure of bacterial communities, applying functional gene arrays (GeoChip 4.2). The relationship between functional genes and environmental factors was analysed using distance-based multivariate multiple regression. Apparently, both the function and structure of the bacterial communities are impacted by dumping activities. The bacterial community at the dumping centre displayed a significant reduction of its entire functional diversity compared with that found at a reference site. DDX compounds separated bacterial communities of the dumping site from those of un-impacted sites. Thus, bacterial community analyses show great potential as ecological indicators in environmental monitoring.
\end{abstract}

(c) 2013 Elsevier Ltd. All rights reserved.

\section{Introduction}

Coastal regions represent economically valuable areas, which constantly evolve and face a wide range of natural (e.g., storm events or extreme changes in salinity along estuaries) and human-induced (e.g., fisheries or waste disposal) stressors. The combined effects of those stressors might result in a potential synergistic, additive or antagonistic interaction (Niemi et al., 2004), which, in turn, directly (e.g., toxic) and indirectly (habitat availability) affects organisms (Adams, 2005) and might persistently change the ecosystem function. A reliable impact evaluation of these stressors on ecosystems represents a crucial, although complex, task, requiring ecological indicators that deliver information concerning the condition of the environment, provide an early warning signal of changes in the environment, or diagnose the causes of environmental problems (Dale and Beyeler, 2001). However, environmental monitoring programmes observing anthropogenic stressors, such as waste disposal, experience difficulties in applying these indicators. Three main concerns are typically reported: (I) failing to obtain the whole complexity of the system, (II) measuring the wrong variables (organisms) and (III) lack of scientific rigor in choosing valid ecological indicators (Dale and Beyeler, 2001).

\footnotetext{
* Corresponding author. Tel.: +49 4725/819 3233; fax: +49 4725/819 3283.

E-mail addresses: rebecca.stoermer@awi.de, info@sustainable-me.de(R.Störmer) antje.wichels@awi.de (A. Wichels), gunnar.gerdts@awi.de (G. Gerdts).
}

The dredging and dumping of sediments, as a maintenance measure of ports and rivers, represents a major anthropogenic stressor for coastal areas, and the impact of these activities on marine systems is regularly evaluated through environmental monitoring programmes. Worldwide, ports and rivers feature high siltation rates, reflecting erosion and sedimentation. In addition, the expansion of global trade requires increasingly large container ships and the constant deepening of waterways. Thus, dredging and dumping activities are inevitable to ensure navigation (de Nijs et al., 2009; McLoughlin, 2000; Tanner et al., 2000) and are expected to increase in the future (OSPAR, 2000).

The disposal of dredged sediments in marine systems poses a potential risk for coastal areas, and multiple implications have been reported. In addition to the increase of contaminants, dumping causes physical disturbances, the burial of benthic organisms and a general change in substrate matter, which might also affect benthic communities (OSPAR, 2009). The evaluation of these implications is regulated through international conventions, such as the London Convention (IMO, 2000), complemented through regional conventions (OSPAR, 2004). The directives for the management of dredged material suggest the assessment of the physical, chemical and biological parameters of both the dredged sediment and dumping sites to estimate the impact of the disposal (IMO, 2000; OSPAR, 2004).

Recommended biological investigations are generally focused on higher organisms, such as fishes and macrozoobenthos and ecotoxicological assessments are frequently performed. However, the execution of these management directives depends on the national 
politics of the signatory countries (Bartels, 2000). Recently, the OSPAR commission claimed to focus more effort on investigating the biological responses to the disposal of dredged material (OSPAR, 2009).

Currently, microbenthic communities (including bacteria) are disregarded in the prescribed directives for the handling of dredged material. Based on the criteria for ecological indicators, according to Dale and Beyeler (2001), microbenthic communities might represent a suitable enhancement for environmental monitoring programmes. According to these authors, ecological indicators need to be easily measurable and sensitive to stresses on the system. Molecular approaches, such as functional gene arrays, facilitate a relatively easy assessment of the information in the microbenthic community, including community structure and function (Lu et al., 2012). Various studies have demonstrated the capacity of functional gene arrays to detect microbial community responses to environmental stressors (He et al., 2007, 2010; Liu et al., 2010; Wang et al., 2009; Ward et al., 2007; Wu et al., 2008; Yergeau et al., 2007; Zhou, 2003), including heavily contaminated habitats (Lu et al., 2012; Neufeld et al., 2006; Van Nostrand et al., 2009; Xie et al., 2011). The results of these studies and other approaches evaluating the response of bacterial communities on environmental perturbation (chemically or physically) have demonstrated changes in the respective community structure and function (dos Santos et al., 2011; Findlay et al., 1990; Suarez-Suarez et al., 2011), thereby forming the basis for our hypothesis.

The global focus of the present study is to evaluate bacterial community analyses as ecological indicators in environmental monitoring programmes. For this purpose, nine representative samples from the dumping centre, the immediate surroundings, a reference site and the sediment origin were obtained from an active dumping site in the German Bight, North Sea. The functional structure of the bacterial communities was assessed via functional gene array GeoChip 4.2 (Lu et al., 2012), containing probes targeting carbon cycling, nitrogen cycling and heavy metal resistance. Two main aspects were addressed in detail: (a) the diversity of functional genes and (b) the environmental factors influencing the functional gene structure of the bacterial community.

\section{Material and methods}

\subsection{Site description and sampling}

The dumping site was located in the southern part of the German Bight $\left(54^{\circ} 03 \mathrm{~N} 07^{\circ} 58 \mathrm{E}\right)$ at $15 \mathrm{~km}$ south off the island of Helgoland. The current in this area is cyclonic and influenced by east wind forcing (Staneva et al., 2009) and the discharge of the adjacent rivers (Howarth, 2001). The water depths range between 20 and $35 \mathrm{~m}$. All sampling sites, including the reference site, were selected by the responsible authorities. The dumping and reference sites are located approximately $12 \mathrm{~km}$ apart (Fig. 1). The dredging zone in the Elbe River (53 $32^{\prime} \mathrm{N}^{\circ} 56^{\prime} \mathrm{E}$ ) has a depth of $13 \mathrm{~m}$.

For the present study, nine representative samples, based on significant differences regarding the bacterial community structure, were chosen (Fig. 1). Eight samples were obtained from the dumping and reference sites. In addition, one sample was obtained from the dredging zone in the Elbe River and included in the analysis (Fig. 1). Sampling took place in August 2009. The last dumping activity was executed in October 2008. All sediment samples were obtained using a van Veen grab $\left(0.1 \mathrm{~m}^{3}\right)$. For coherent analyses, the sediment was filled into a clean metal box and homogenised. Both samples for the analyses of the bacterial communities and samples for the physiochemical analyses were obtained from the same sediment. For the analysis of the bacterial communities, three subsamples were stored immediately after sampling at $-20^{\circ} \mathrm{C}$ in 50-mL Falcon tubes.

\subsection{Environmental data analysis}

All environmental data (Table 1) were provided from the Hamburg Port Authority (HPA). The total fraction of the sediment was analysed according to the HABAK guidelines (BfG, 1999). Briefly,

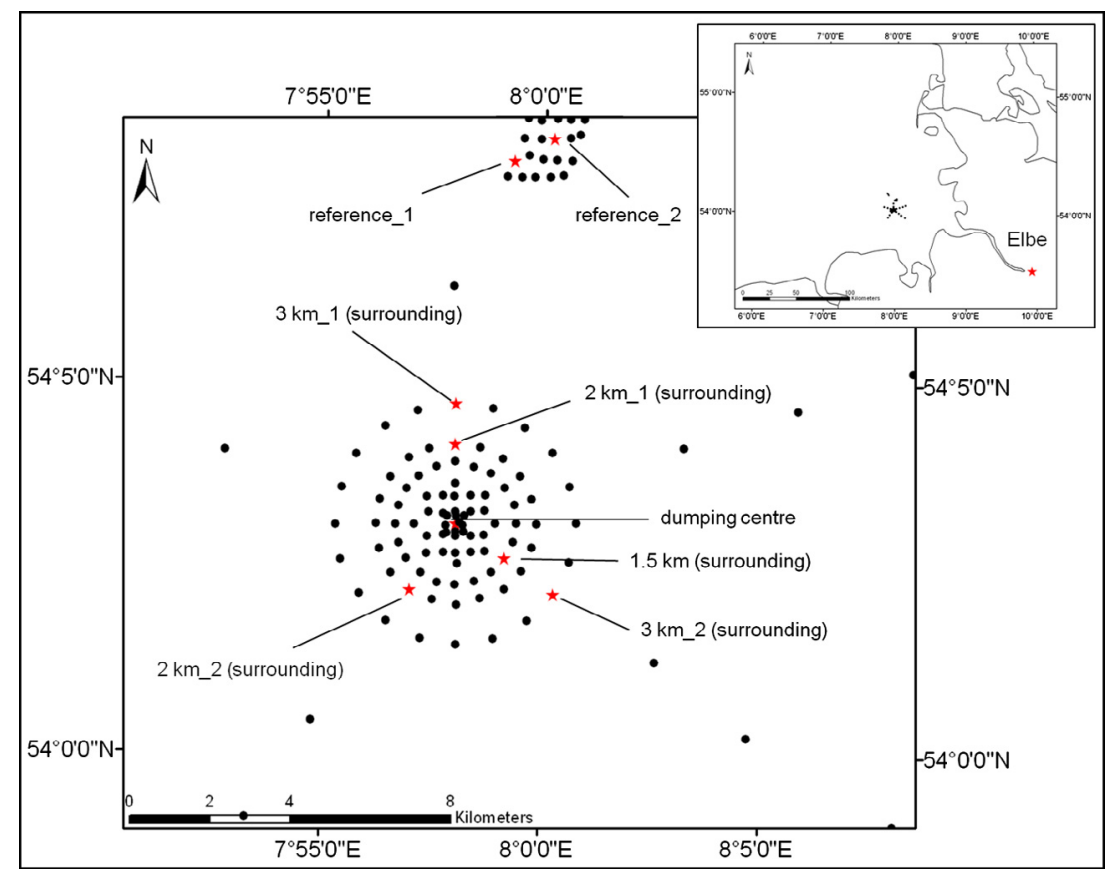

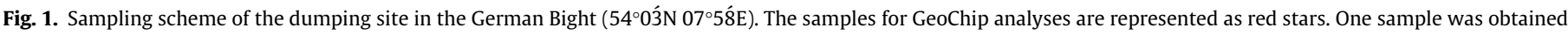

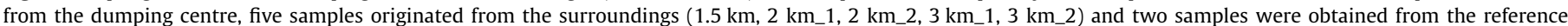

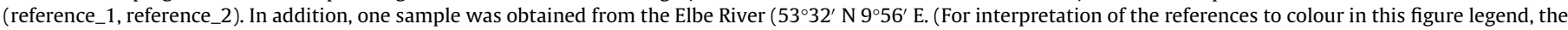
reader is referred to the web version of this article.) 
Table 1

Overview environmental data set.

\begin{tabular}{|c|c|}
\hline Grain size fractions & Hexachlorocyclohexane $(\mathrm{HCH})$ \\
\hline$<20 \mu \mathrm{m}$ & AlphaHCH \\
\hline $20-63 \mu \mathrm{m}$ & BetaHCH \\
\hline $63-100 \mu \mathrm{m}$ & GammaHCH \\
\hline $100-200 \mu \mathrm{m}$ & DeltaHCH \\
\hline \multicolumn{2}{|l|}{$200-630 \mu \mathrm{m}$} \\
\hline $630-1000 \mu \mathrm{m}$ & $\begin{array}{l}\text { Dichlorodiphenyldichloroethane (DDT) and } \\
\text { metabolites }\end{array}$ \\
\hline $1000-2000 \mu \mathrm{m}$ & $\begin{array}{l}\text { ppDDE } \\
\text { opDDD }\end{array}$ \\
\hline$S, N, P, C$ & ppDDD \\
\hline TOC $(C)$ & opDDT \\
\hline Nitrogen $(\mathrm{N})$ & ppDDT \\
\hline \multicolumn{2}{|l|}{ Sulphur (S) } \\
\hline Phosphorus (P) & $\begin{array}{l}\text { Organotin compounds } \\
\text { Monobutyltin (MBT) }\end{array}$ \\
\hline Hydrocarbons & $\begin{array}{l}\text { Dibutyltin (DBT) } \\
\text { Tributyltin (TBT) }\end{array}$ \\
\hline $\begin{array}{l}\text { Polycyclic aromatic } \\
\text { hydrocarbons }(P A H)\end{array}$ & Tetrabutyltin \\
\hline \multicolumn{2}{|l|}{ Naphthaline } \\
\hline Fluorene & Heavy metals \\
\hline Phenanthrene & Arsenic \\
\hline Anthracene & Lead \\
\hline Fluoranthene & Cadmium \\
\hline Pyrene & Chrome \\
\hline Benz(a)anthracene & Copper \\
\hline Chrysene & Nickel \\
\hline Benzo(b)fluoranthene & Mercury \\
\hline Benzo(k)fluoranthene & Zinc \\
\hline \multicolumn{2}{|l|}{ Benzo(a)pyrene } \\
\hline \multicolumn{2}{|l|}{ Dibenz(ah)anthracene } \\
\hline \multicolumn{2}{|l|}{ Benzo(ghi)perylene } \\
\hline \multicolumn{2}{|l|}{ Indeno(1.2.3cd)pyrene } \\
\hline \multicolumn{2}{|l|}{ Chlorinated Diphenyls (PCB) } \\
\hline \multicolumn{2}{|l|}{ РCB28 } \\
\hline \multicolumn{2}{|l|}{ PCB52 } \\
\hline \multicolumn{2}{|l|}{ PCB101 } \\
\hline \multicolumn{2}{|l|}{ PCB118 } \\
\hline \multicolumn{2}{|l|}{ PCB138 } \\
\hline \multicolumn{2}{|l|}{ PCB153 } \\
\hline PCB180 & \\
\hline
\end{tabular}

Table 2

Sediment characteristics for the sampling sites.

\begin{tabular}{ll}
\hline Site & Sediment \\
\hline Elbe & Muddy sand \\
dumping centre & Clayey sand \\
$1.5 \mathrm{~km}$ & Sandy mud \\
$2 \mathrm{~km} \_1$ & Sandy clay \\
$2 \mathrm{~km} \_2$ & Sandy clay \\
$3 \mathrm{~km} \_1$ & Sandy clay \\
$3 \mathrm{~km} \_2$ & Sandy clay \\
reference_1 & Sandy mud \\
reference_2 & Sandy mud \\
\hline
\end{tabular}

the sediments were analysed for their respective proportion of grain size fractions (\% of dry weight) and content of heavy metals, elemental sulphur, nitrogen, phosphorous, total organic carbon and organic pollutants (except organotin and dichlorodiphenylchloroethane $(\mu \mathrm{g} / \mathrm{kg}$ dry weight)) in $\mathrm{mg} / \mathrm{kg}$ dry weight (see Table 2).

\subsection{DNA-extraction, amplification and labelling}

The PowerSoil DNA Isolation Kit (Catalogue Nr. 12888-100; MoBio Laboratories, Carlsbad, CA) was used for the DNA extraction according to the manufacturer's protocol. Three individual extractions (subsamples a, b and c) of $0.25 \mathrm{~g}$ sediment were performed, and the extracted DNA was eluted in $50 \mu \mathrm{L}$ elution buffer. The genomic DNA concentrations were measured in duplicate through photometry using the Infinite M200 (Tecan Austria GmbH, Grödig, Austria). The amplification and hybridisation were performed at Glomics Inc. (Norman, Oklahoma, USA). Approximately $100 \mathrm{ng}$ of DNA was amplified using the Templiphi kit (GE Healthcare, Piscataway, NJ, USA), with modifications. The amplified DNA ( $2 \mu \mathrm{g})$ was labelled with Cy3 using random primers and the Klenow fragment of DNA polymerase I (Wu et al., 2006) and dried in a SpeedVac $\left(45^{\circ} \mathrm{C}, 45\right.$ min: ThermoSavant, Milford, MA, USA) before hybridisation (Lu et al., 2012).

\subsection{GeoChip 4.2 hybridisation and data pre-processing}

The samples were analysed using GeoChip 4.2, updated from GeoChip 4.0 (Hazen et al., 2010; Lu et al., 2012) with more genes derived from fungi and soil-borne pathogens. The gene array contains 103,666 probes targeting functional genes assigned to several gene categories (antibiotic resistance, bacteria phage interaction, energy process, fungi function, carbon, nitrogen, sulphur and phosphorus cycling, metal resistance, organic contaminant degradation, soil benefit, soil borne pathogen, stress and virulence). All hybridisations were performed at $42{ }^{\circ} \mathrm{C}$ with $40 \%$ formamide for $16 \mathrm{~h}$ on a MAUI hybridisation station (BioMicro, Salt Lake City, UT, USA). After hybridisation, the arrays were scanned (NimbleGen MS 200, Madison, WI USA) at 100\% laser power. The signal intensities were measured based on the scanned images, and spots with signal-to-noise ratios lower than two were removed before statistical analysis, as previously described (He et al., 2010; Lu et al., 2012). All procedures were performed at Glomics Inc. (Norman, Oklahoma, USA). In addition, the singletons, positive probes detected solely in one of the subsamples, were discarded prior to the statistical analyses to remove noise from the data set.

\subsection{Statistical analysis}

\subsubsection{Univariate statistics}

Differences in the relative abundance of functional genes among samples were assessed using one-way analysis of variance (ANOVA, Statistica Version 7.1, StatSoft GmbH, Hamburg, Germany) for individual gene categories. For the ANOVA tests, the calculated percentage of functional genes were arcsine square root transformed and a significance level of $p<0.05$ was applied. Pairwise comparisons of the samples were tested using post hoc Tukey's HSD tests $(p<0.05)$.

\subsubsection{Hierarchical clustering}

For individual gene categories, cluster analyses (CLUSTER 3.0; http://www.eisenlab.org) were performed. The Euclidian distance was applied as the similarity metric. This metric represents one of the most common methods used to investigate gene expression in microarrays (Jiang et al., 2004). Unlike correlation-based distance measures (e.g., Pearson correlation), the Euclidean distance similarly considers the differences and changes in the magnitude of the gene expression levels (de Hoon, 2002), and this method has been previously applied in several studies (Hoon et al., 2002; Liu et al., 2010; Wawrik et al., 2012; Wu et al., 2008; Zhang et al., 2013). All data sets were log transformed prior to analysis. The two-way hierarchical clustering was based on the average linkage method, and the results were visualised using TREEVIEW software (http://www.eisenlab.org) (Eisen et al., 1999). 
Table 3

Geochemistry of the sampling sites.

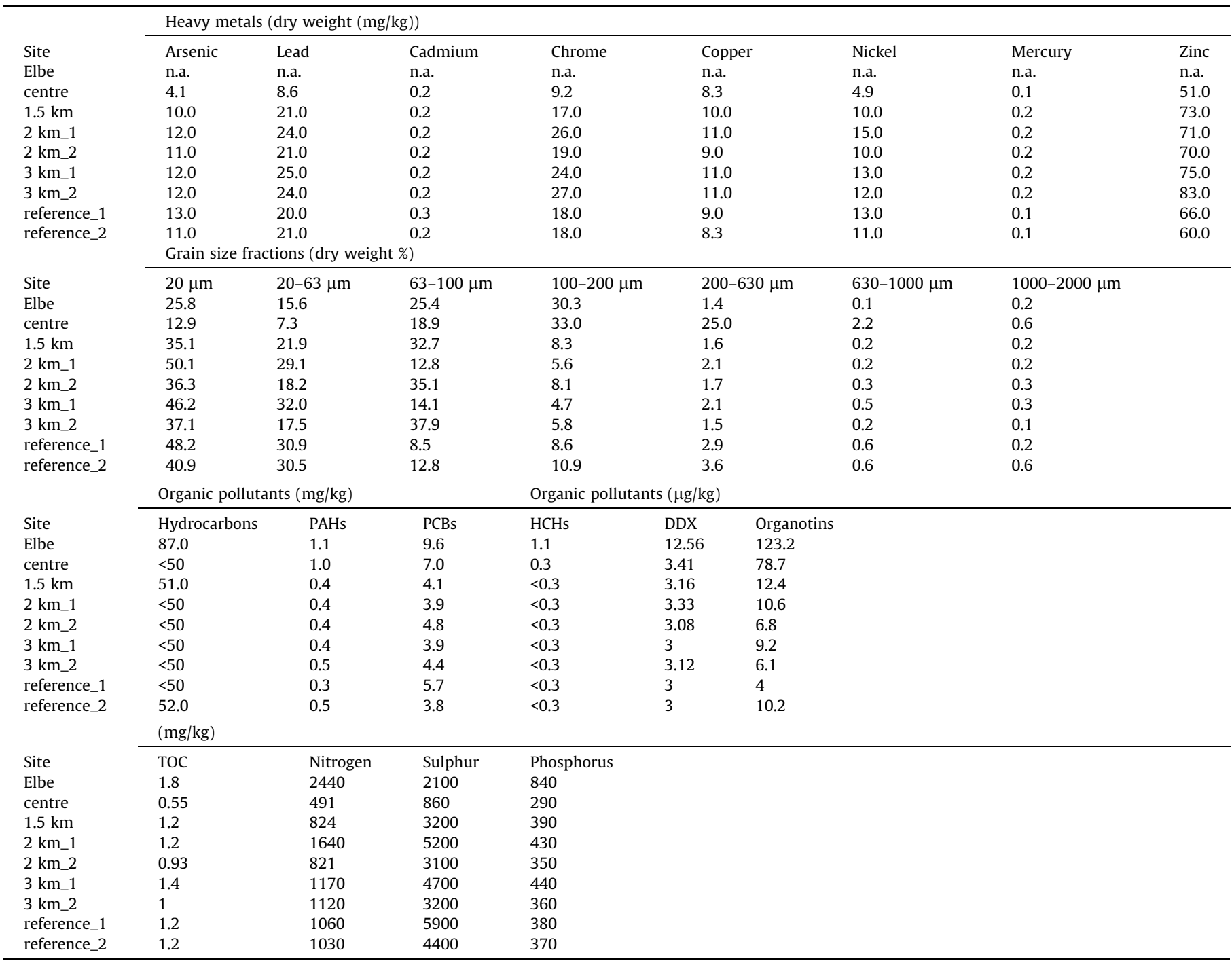

\subsubsection{Multivariate statistics}

Individual gene categories were compared using the 2STAGE analysis in the PRIMER package (PRIMER Version 6, PRIMER-E Ltd, Lutton, UK) (Clarke and Gorley, 2006). The resemblance matrices of individual gene categories were calculated, applying Euclidean distance to ensure the comparability of the results with those obtained via hierarchical clustering. Spearman's rank correlation was applied to correlate the individual resemblance matrices of the gene categories in pairwise comparisons. For cluster analysis, the group average method was applied.

Prior to the distance-based multivariate multiple regression analysis, the environmental variables were tested for (multi) collinearity via pairwise correlations (PRIMER Version 6, PRIMER-E Ltd., Lutton, UK), applying Spearman's rank correlation. We observed high positive and negative correlation values $\left(r_{s}>0.95\right)$ for the $20 \mu \mathrm{m}$ and $200-630 \mu \mathrm{m}$ grain size fractions and sulphur with several other environmental variables (SM1). Consistent with Sun et al. (2012), even the two variables revealing high correlation values were maintained for the analysis. For the multivariate analysis, all factors were included, and a step-wise selection procedure was performed to ensure that those factors sufficiently explaining most of the variance in the structure of functional genes were included in the model (see multivariate statistics) (Anderson et al., 2008).

The relationship between functional genes and environmental variables was investigated using distance-based multivariate multiple regression (DISTLM). We used a qualitative approach to elucidate this survey, as not all genes provided values for all three subsamples, and the means of these values showed less validity for the analysis. To calculate the binary table, only genes that showed positive hybridisation signals in at least two of the subsamples were considered. The environmental variables, including grain size fraction, sulphur $(\mathrm{S})$, nitrogen $(\mathrm{N})$, phosphorus $(\mathrm{P})$, total organic carbon (C) and heavy metals, were considered as single values, and the polyaromatic compounds (PAH), polychlorinated biphenyls (PCB), (hexachlorocyclohexane) ( $\mathrm{HCH})$ and dichlorodiphenylchloroethane (DDX) single compounds were summed for each category. The environmental data were log transformed prior to the analysis, and the Jaccard Index was applied to calculate the resemblance matrix for functional genes. The DISTLM model was built using step-wise selection. This selection procedure is initiated as a forward selection but attempts to improve the model continuously through a potential backward elimination at every step (Clarke and Gorley, 2006). The adjusted $R^{2}$ and 999 permutations were applied at a significance level of $p<0.05$ as selection criteria. 
Table 4

Similarities (\%) among subsamples based on gene overlap as derived from GeoChip 4.2 analysis.

\begin{tabular}{|c|c|c|c|c|}
\hline Site & & $a(\%)$ & $b(\%)$ & c \\
\hline Elbe & $\begin{array}{l}a \\
b \\
c\end{array}$ & $\begin{array}{l}75 \\
80\end{array}$ & 81 & \\
\hline dumping centre & $\begin{array}{l}a \\
b \\
c\end{array}$ & $\begin{array}{l}82 \\
80\end{array}$ & 83 & \\
\hline $1.5 \mathrm{~km}$ & $\begin{array}{l}a \\
b \\
c\end{array}$ & $\begin{array}{l}70 \\
84\end{array}$ & 76 & \\
\hline 2 km_1 & $\begin{array}{l}a \\
b \\
c\end{array}$ & $\begin{array}{l}81 \\
83\end{array}$ & 81 & \\
\hline $2 \mathrm{~km} \_2$ & $\begin{array}{l}a \\
b \\
c\end{array}$ & $\begin{array}{l}67 \\
79\end{array}$ & 77 & \\
\hline 3 km_1 & $\begin{array}{l}a \\
b \\
c\end{array}$ & $\begin{array}{l}84 \\
83\end{array}$ & 76 & \\
\hline $3 \mathrm{~km} \_2$ & $\begin{array}{l}a \\
b \\
c\end{array}$ & $\begin{array}{l}87 \\
87\end{array}$ & 83 & \\
\hline reference_1 & $\begin{array}{l}a \\
b \\
c\end{array}$ & $\begin{array}{l}86 \\
84\end{array}$ & 87 & \\
\hline reference_2 & $\begin{array}{l}a \\
b \\
c\end{array}$ & $\begin{array}{l}81 \\
86\end{array}$ & 87 & \\
\hline
\end{tabular}

The results were visualised using distance-based redundancy analysis (dbRDA).

\section{Results}

\subsection{Geochemical description of the study sites}

All parameters obtained from the entire sediment are summarised in Table 3. According to the particle size analysis, the sediments at the dumping site were characterised as sand, whereas the reference site sediment comprised sandy mud (Table 1). The dumping centre had the highest values for the grain size fractions at $100-200 \mu \mathrm{m}$ and $200-630 \mu \mathrm{m}$ (medium sand). Organic pollutants, namely, PAHs, PCBs and organotin compounds, were highest in the Elbe River and at the dumping centre. In contrast, the concentrations of sulphur, nitrogen, carbon and phosphorus and heavy metals were lowest at the dumping centre. The highest TOC, nitrogen and phosphorous concentrations were detected in the Elbe River. The reference site, characterised as sandy mud, exhibited its highest TOC, nitrogen and phosphorous concentration values in the $20-63 \mu \mathrm{m}$ grain size fraction.

\subsection{Overview of the entire functional gene diversity}

Initially, we investigated the performance of the GeoChip 4.2, considering gene overlap and the number of detected genes for individual gene categories and subsamples. A total of 15,644 genes (singletons) were removed from the data set and 18,787 genes remained for further analyses. The subsamples were compared for similarity according to gene overlap. The relative overlap among the subsamples is shown in Table 4 . In general, we observed high similarity ( $>80 \%$ ) among the subsamples. Furthermore, we examined individual gene categories to obtain an overview of the detected genes in relation to the total genes covered by the GeoChip 4.2 (Table 5). We observed the highest coverage for the following gene categories: organic remediation (25.03\%), energy processing $(23.93 \%)$ metal resistance $(23.23 \%)$, soil benefit (21.11\%), phosphorous cycling (20.61\%) and carbon cycling (20.35\%) (Table 5).

\subsection{Relationship between sampling site and functional diversity}

The potential relationships between the relative abundance of functional genes (functional diversity) of the bacterial community and the sampling sites were tested using one-way analysis of variance (ANOVA). In general, the Elbe River had the highest functional diversity regarding all individual gene categories (Supplemental material: SM2, SM3, SM4), and this was found to be statistically significant. In contrast, the functional diversity of the bacterial community at the dumping centre was significantly lower compared with the reference site and Elbe River (Supplemental material: SM2, SM3 and SM4). The distribution of functional genes pooled in the gene category 'organic remediation' is depicted in Fig. 2 and the corresponding ANOVA results are presented in Table 6 . Approximately $16 \%$ of the total genes associated with 'organic remediation' were detected in the Elbe River. In contrast, the bacterial communities from the dumping site and immediate surroundings ( $1.5 \mathrm{~km}, 2 \mathrm{~km} \_1$ ) displayed only $10 \%$ of these genes. Considering only the marine sampling sites (excluding the Elbe River), the bar chart and ANOVA results show the highest functional diversity for bacterial communities at the reference site ( $\sim 13 \%$ of total genes, Fig. 2, Table 6 ) and this was found to be statistically significant.

Table 5

Overview of total and detected probes and their percentage for individual gene categories as derived from the GeoChip 4.2 .

\begin{tabular}{|c|c|c|c|c|c|}
\hline Gene category & Antibiotic resistance & Bacteria phage & Carbon cycling & Energy process & Fungi function \\
\hline No. total probes & 3334 & 1071 & 11065 & 840 & 4557 \\
\hline No. Detected probes & 698 & 109 & 2252 & 201 & 911 \\
\hline$\%$ & 20.94 & 10.18 & 20.35 & 23.93 & 19.99 \\
\hline Gene category & Metal resistance & Nitrogen cycling & Organic Remediation & Other category & Phosphorus \\
\hline No. total probes & 9272 & 12680 & 17061 & 3511 & 1349 \\
\hline No. Detected probes & 2154 & 1234 & 4270 & 301 & 278 \\
\hline$\%$ & 23.23 & 9.73 & 25.03 & 8.57 & 20.61 \\
\hline Gene category & Soil benefit & Soil borne pathogen & Stress & Sulphur & Virulence \\
\hline No. total probes & 3870 & 1454 & 21597 & 7101 & 3738 \\
\hline No. Detected probes & 817 & 260 & 3825 & 775 & 678 \\
\hline$\%$ & 21.11 & 17.88 & 17.71 & 10.91 & 18.14 \\
\hline
\end{tabular}




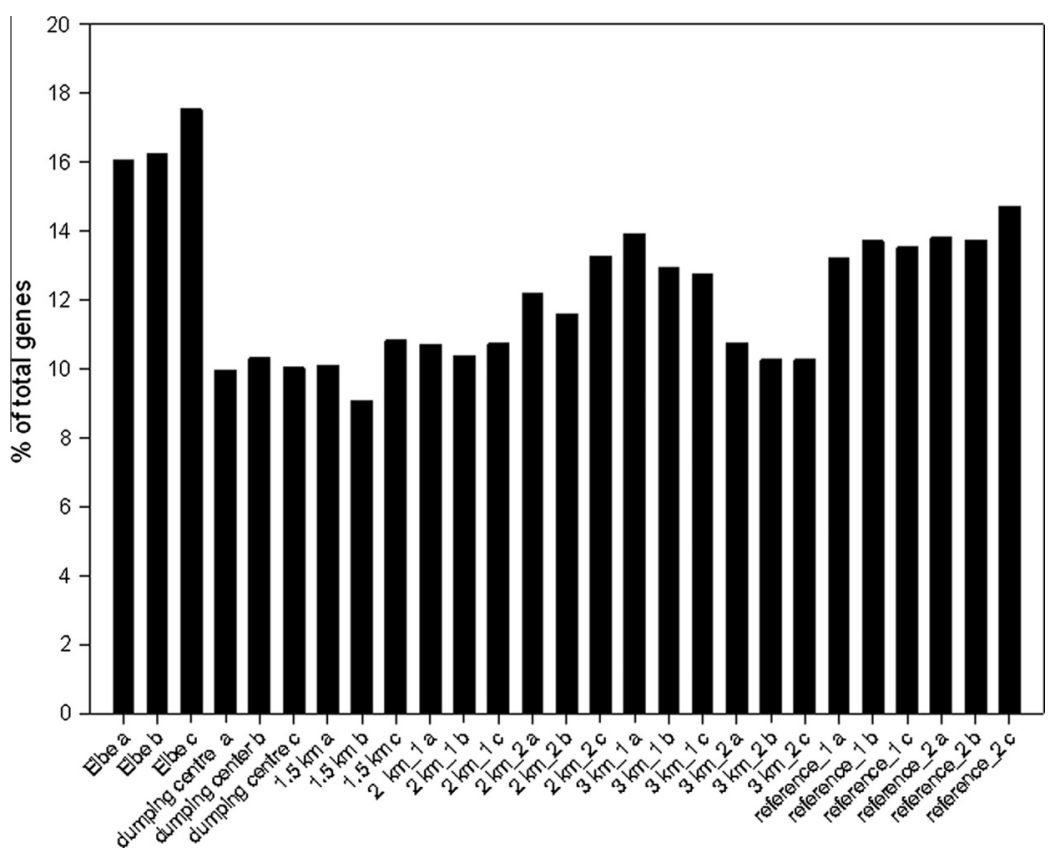

Fig. 2. Bar chart displaying the relative abundance of the genes belonging to the gene category 'organic remediation' in the different samples.

Table 6

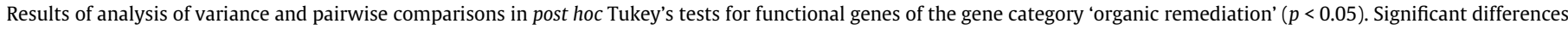
are bold.

\begin{tabular}{|c|c|c|c|c|c|c|c|c|c|c|c|c|c|c|c|}
\hline & SQ & FG & MQ & $F$ & $p$ & & Elbe & $\begin{array}{l}\text { dumping } \\
\text { centre }\end{array}$ & $\begin{array}{l}1.5 \\
\mathrm{~km}\end{array}$ & $\begin{array}{l}2 \\
\mathrm{~km} \_1\end{array}$ & $\begin{array}{l}2 \\
\mathrm{~km} \_2\end{array}$ & $\begin{array}{l}3 \\
\mathrm{~km} \_1\end{array}$ & $\begin{array}{l}3 \\
\mathrm{~km} \_2\end{array}$ & reference_1 & reference_2 \\
\hline & & & & & & Elbe & & 0.000 & 0.000 & 0.000 & 0.000 & 0.000 & 0.000 & 0.000 & 0.003 \\
\hline & & & & & & $\begin{array}{l}\text { dumping } \\
\text { centre }\end{array}$ & 0.000 & & 1.000 & 0.962 & 0.003 & 0.000 & 0.998 & 0.000 & 0.000 \\
\hline Constante & 3.451 & 1 & 3.451 & 44153.18 & 0.000 & $1.5 \mathrm{~km}$ & 0.000 & 1.000 & & 0.880 & 0.002 & 0.000 & 0.981 & 0.000 & 0.000 \\
\hline Site & 0.027 & 8 & 0.003 & 43.72 & 0.000 & $2 \mathrm{~km} \_1$ & 0.000 & 0.962 & 0.880 & & 0.028 & 0.001 & 1.000 & 0.000 & 0.000 \\
\hline \multirow[t]{5}{*}{ Error } & 0.001 & 18 & 0.000 & & & $2 \mathrm{~km} \_2$ & 0.000 & 0.003 & 0.002 & 0.028 & & 0.698 & 0.012 & 0.372 & 0.046 \\
\hline & & & & & & 3 km_1 & 0.000 & 0.000 & 0.000 & 0.001 & 0.698 & & 0.000 & 1.000 & 0.693 \\
\hline & & & & & & $3 \mathrm{~km} \_2$ & 0.000 & 0.998 & 0.981 & 1.000 & 0.012 & 0.000 & & 0.000 & 0.000 \\
\hline & & & & & & reference_1 & 0.000 & 0.000 & 0.000 & 0.000 & 0.372 & 1.000 & 0.000 & & 0.942 \\
\hline & & & & & & reference_2 & 0.003 & 0.000 & 0.000 & 0.000 & 0.046 & 0.693 & 0.000 & 0.942 & \\
\hline
\end{tabular}

\subsection{Hierarchical clustering of individual gene categories}

In addition to functional diversity, the functional structure of the bacterial communities was of great interest in the present study. For this purpose, we applied two-way hierarchical clustering and 2STAGE analyses to characterise the potential relationships between the functional structure of the bacterial communities and the sampling sites for individual gene categories. The dendrogram generated from the 2STAGE analysis indicated high similarities $\left(r_{s}>0.8\right)$ for the functional structure of the bacterial communities comparing all individual gene categories (Fig. 3). Hierarchical clustering was applied to visualise the differences in the abundance of functional genes across the sampling sites with respect to individual gene categories. The clustering was performed for each gene category to determine the potential differences for individual gene categories and thus functional processes (e.g., heavy metal resistance, organic remediation), considering the different sampling sites. Consistent with the 2STAGE analysis, individual hierarchical cluster analyses revealed a highly congruent pattern comparing all gene categories. Exemplarily, the hierarchical clustering for the gene category 'organic remediation' is depicted in Fig. 4. The horizontal cluster persistently displayed three cluster groups for all gene categories: (I) samples from the Elbe River, (II) samples from the dumping centre and part of the surrounding area ( $1.5 \mathrm{~km}, 2 \mathrm{~km} \_1,2 \mathrm{~km} \_2$, and $3 \mathrm{~km} \_2$ ) and (III) samples from the reference site and $3 \mathrm{~km} \_1$. In general, we observed (a) genes detected in all samples, (b) genes detected in only the "Elbe" group, (c) genes detected in the "dumping centre" group and (d) genes detected in the "reference" group (Fig. 4). All groups contained similar functional genes. However, we detected differences regarding the organisms from which those functional genes were isolated. The functional genes present in the Elbe River predominantly originated from Betaproteobacteria, whereas the functional genes detected in the samples from the reference site were predominantly derived from Gammaproteobacteria and Deltaproteobacteria. The dumping site comprised functional genes of all phylogenetic types (data not shown).

\subsection{Relationship between environmental factors and functional genes}

The relationship between functional genes and environmental factors was investigated using a distance-based multiple regression model (DISTLM), and the results were visualised using a distance-based redundancy analysis (Fig. 5). The influence of 


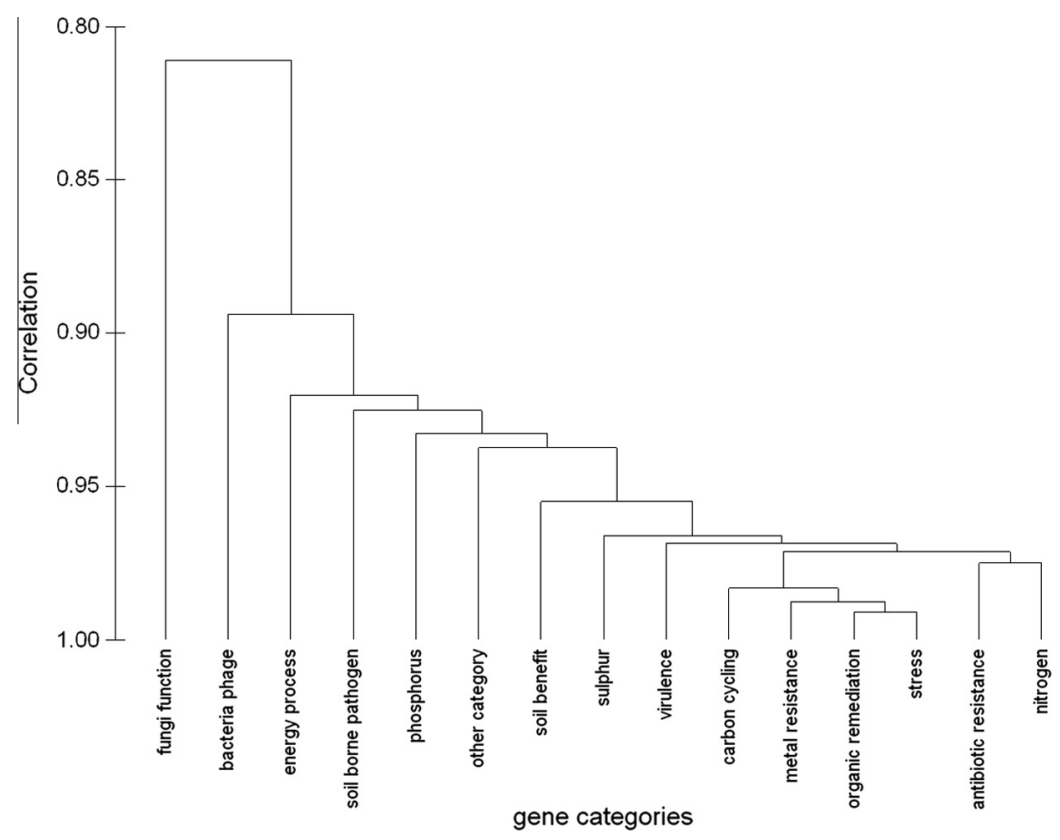

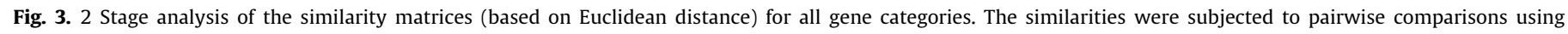
Spearman'-s rank correlation.

dumping activity on the functional structure of the bacterial communities in the sediments was estimated comparing communities from dumping and reference sites. The marginal effects of all environmental variables in the step-wise regression model are summarised in Table 7. Briefly, individual substances belonging to organic pollutants, such as DDX, explain most of the variation in the functional structure of the bacterial community, considering the explanatory variables separately. Furthermore, the individual grain size classes demonstrated a major influence, explaining between $10 \%$ and $19 \%$ of the variation in the model. The distance-based redundancy analysis (dbRDA) displays the conditional effects of environmental variables (Fig. 5, Table 8). The concentration of DDX significantly explained most of the variation, followed by zinc, HCHs, TOC, phosphorous and nitrogen. The first two axes of the dbRDA explained $63.4 \%$ of the total and $67 \%$ of fitted variation (Fig. 5). The DDX compounds correlated well with the first axis, while the other variables were independent, correlating with the second axis of the model. The largest gradient was formed by the variable 'sums of DDX'; separating bacterial communities from the dumping centre and the close surroundings from those of the reference site (Fig. 5).

\section{Discussion}

The results obtained in the present study demonstrated the potential of bacterial community analyses as an ecological indicator in environmental monitoring programmes by investigating differences in the functional gene diversity of marine bacterial communities, comparing samples obtained at a dumping site for dredged river sediment with those of un-impacted (reference) sites. We hypothesised that (a) a pollutant-specific response (increase of functional genes involved in, for example, metal resistance or organic remediation at the dumping site) and (b) the detection of environmental factors (e.g., pollutants) influence the functional structure of bacterial communities at the dumping site.

The bacterial community at the dumping centre displayed a general reduction of functional diversity regarding all gene categories represented on the GeoChip 4.2. Initially, these results seemed contradictory to our first hypothesis (pollutant specific response) and the findings of other studies addressing the impact of organic pollution on bacterial communities. In cases of oil spills and uranium biodegradation, enrichments of gene functions (Lu et al., 2012) and an increase in functional diversity were reported using GeoChip technology (Van Nostrand et al., 2009). The reduced functional diversity in the present study might reflect the dumping process and the hydrographical regime at the dumping site. During the dumping process, the sediment body separates according to respective grain sizes: Coarse sand fractions (including attached bacterial biomass and certain pollutants (e.g., high molecular PAHs)) (Latimer et al., 1999) immediately sink, while fine-grain fractions and attached nutrients and pollutants (such as heavy metals) can be transported through currents for up to $8 \mathrm{~km}$ before settling on the seafloor (HPA, 2005). Thus, consistent with the HPA, the deposit at the dumping centre predominately comprises sandy sediments (grain size analyses) and is relatively poor in sulphur, nitrogen, carbon and phosphorus and heavy metals (HPA, 2009). After the dumping, the dumped sediment is defeated through hydrographical forces at the dumping site: Cyclonic currents, which are constantly influenced through east wind forcing (Staneva et al., 2009) and the discharge of the adjacent rivers (Howarth, 2001), only assures the local impact of the dumping activity for the marine environment. Consequently, the mixing of sediments and, therefore, the bioavailability of both nutrients and pollutants at the dumping site are restricted, likely resulting in a reduced functional diversity of the bacterial community at the dumping site. At present, little is known about the relationship between the functional diversity of bacterial communities and the bioavailability of nutrients or contaminants. Recently, Bienhold et al. (2012) reported a close relationship between energy availability and the functional diversity of sediment bacterial communities, which supports our hypothesis. The bioavailability of sediments is determined through several physicochemical factors, such as temperature, salinity, pH or redox potential (Forstner, 1989; Langston and Pope, 1995). To date, the aspect of the bioavailability of pollutants has not been explicitly addressed in the directives for the environmental monitoring of dumping sites. However, the assessment of a variety of biogeochemical parameters facilitates the investigation of relationships between the functional gene 


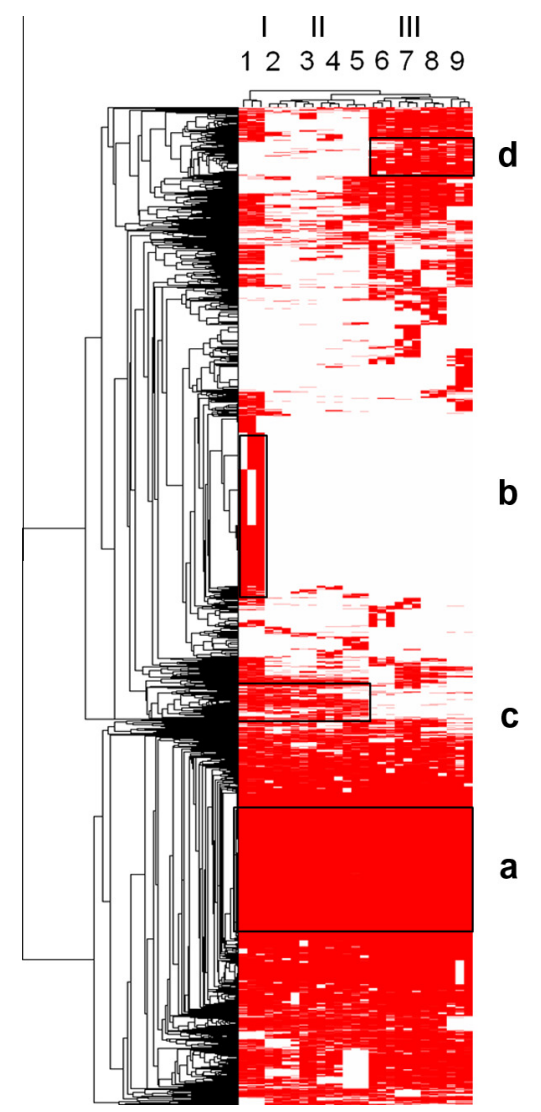

Fig. 4. Hierarchical clustering analysis of the 'organic remediation' genes based on the hybridisation signals, using Euclidean distance. The figure was generated using CLUSTER, applying the average linkage method, and visualised using TREEVIEW. White represents no hybridisation above background level, and red represents positive hybridisation. 1: Elbe River, 2: dumping centre, $3: 1.5 \mathrm{~km}, 4: 2 \mathrm{~km} \_1,5: 3$ $\mathrm{km} \_2,6: 3 \mathrm{~km} \_1,7$ : reference 2 , 8: reference $1,9: 2 \mathrm{~km} \_2$; (I) samples from the Elbe River, (II) samples from dumping centre and surrounding areas $(1.5 \mathrm{~km}, 2$ $\mathrm{km} \_1,2 \mathrm{~km} \_2,3 \mathrm{~km} \_2$ ) and (III) samples from the reference site and $3 \mathrm{~km} \_1$. (a) Genes detected in all samples, (b) genes detected only in the "Elbe" group, (c) genes detected in the "dumping centre" group, and (d) genes detected in the "reference" group. (For interpretation of the references to colour in this figure legend, the reader is referred to the web version of this article.)

structure and these parameters using multivariate analyses. In the present study, the distLM approach was used to calculate the significant influence of DDX compounds on the bacterial community structure, suggesting that the biogeochemical conditions at the dumping site influence the functional diversity of the bacterial community. The significant influence of environmental factors on the functional diversity of bacterial communities was previously reported in similar studies investigating the relationships between the diversity of functional genes and environmental factors (Waldron et al., 2009; Xie et al., 2011). Waldron and co-workers observed lower gene diversity in highly contaminated samples and the significant influence of contaminants on the functional structure of the bacterial communities, consistent with the results presented herein. However, the accurate determination of explicit factors influencing the bacterial community remains elusive. Particularly, due to the determination of high positive correlations between the recorded environmental factors in field studies (DeanRoss and Mills, 1989; Gillan et al., 2005). Considering the results of Spearman's rank correlation, in the present study, we detected considerable positive correlations ( $\rho \sim 0.7$ ) of the DDX compounds with organotin and $\mathrm{HCH}$ compounds. Hence, the significant effect of DDX compounds might reflect the combination of several substances. An approach to determine these combined effects

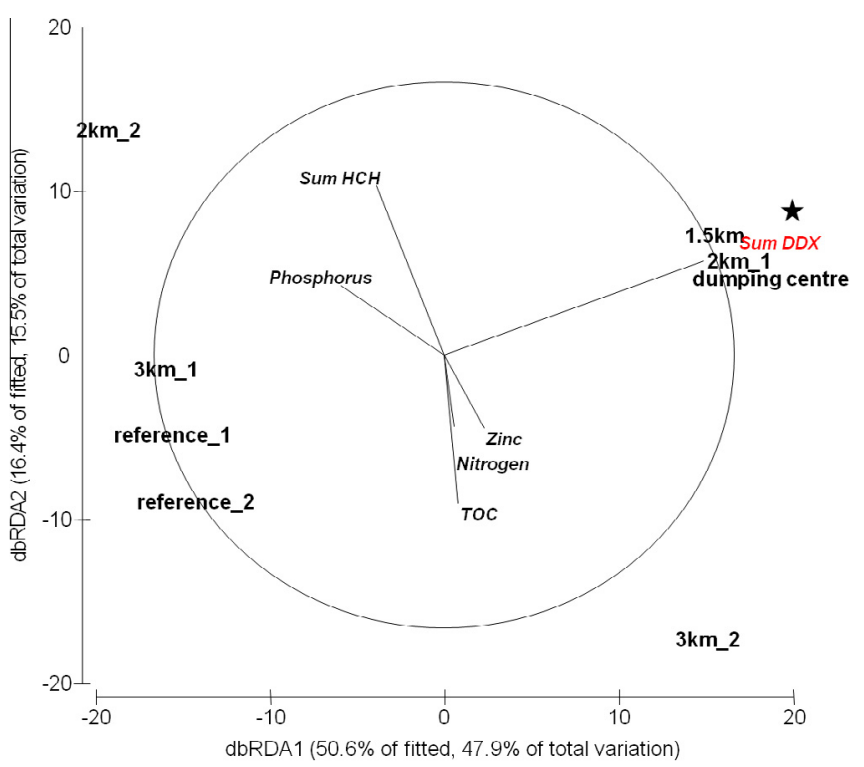

Fig. 5. dbRDA plot of bacterial community's functional gene structure fitted predictor variables determined by step-wise selection distLM. Lengths of overlaid vectors indicate the relative influence of the fitted predictor variable and significant $(\mathrm{p}<0.001)$ environmental factors are displayed in red and are marked with a star. (For interpretation of the references to colour in this figure legend, the reader is referred to the web version of this article.)

Table 7

Marginal effects of environmental variables obtained from DISTLM applying a stepwise selection procedure $(p<0.05)$. Significant values in bold.

\begin{tabular}{llll}
\hline Variable & Pseudo- $F$ & $P$ & Proportion of variance \\
\hline TOC & 10078.00 & 0.4268 & 0.14381 \\
$20 \mu \mathrm{m}$ & 10763.00 & 0.3643 & 0.1521 \\
$20-63 \mu \mathrm{m}$ & 1423.00 & 0.2202 & 0.1917 \\
$63-100 \mu \mathrm{m}$ & 0.73044 & 0.633 & 0.10853 \\
$100-200 \mu \mathrm{m}$ & 0.88282 & 0.6238 & 0.12826 \\
$200-630 \mu \mathrm{m}$ & 0.93255 & 0.5401 & 0.13452 \\
$630-1000 \mu \mathrm{m}$ & 0.63225 & 0.917 & 0.095329 \\
$1000-2000 \mu \mathrm{m}$ & 0.57582 & 0.7616 & 0.087567 \\
Nitrogen & 0.5713 & 0.834 & 0.086939 \\
Sulphur & 11854.00 & 0.2821 & 0.16498 \\
Phosphorus & 0.62592 & 0.7759 & 0.094466 \\
Hydrocarbons & 0.48875 & 0.8231 & 0.075323 \\
PAH & 11404.00 & 0.3278 & 0.15971 \\
PCB & 0.53721 & 0.8477 & 0.082178 \\
HCH & 17204.00 & 0.2133 & 0.22284 \\
DDX & 32957.00 & $\mathbf{0 . 0 0 5 1}$ & $\mathbf{0 . 3 5 4 5 4}$ \\
Organotin & 11783.00 & 0.2302 & 0.16415 \\
Arsenic & 12273.00 & 0.2526 & 0.16982 \\
Lead & 0.80874 & 0.6911 & 0.11878 \\
Cadmium & 0.49479 & 0.9353 & 0.076182 \\
Chrome & 0.68117 & 0.7028 & 0.10195 \\
Copper & 0.84929 & 0.4593 & 0.124 \\
Nickel & 0.73634 & 0.6677 & 0.10931 \\
Mercury & 0.7963 & 0.5245 & 0.11717 \\
Zinc & 0.59201 & 0.7974 & 0.089807 \\
\hline
\end{tabular}

might include a combination of controlled laboratory experiments, manipulation of single factors, and field studies. Furthermore, additional, physicochemical parameters, such as temperature, $\mathrm{pH}$, oxygen penetration or redox potentials, might be measured to estimate the bioavailability of pollutants for bacterial communities in future monitoring programmes.

Apparently, not only the functionality but also the community structure of local bacterial communities at the dumping centre is impacted through dumping activity. The detection of Betaproteobacteria, representing typical freshwater organisms (Miskin et al., 
Table 8

Sequencial effects of environmental variables obtained from DISTLM applying a stepwise selection procedure $(p<0.05)$. Significant values in bold.

\begin{tabular}{llll}
\hline Variable & Pseudo- $F$ & $P$ & Proportion of variance \\
\hline DDX & 32957.00 & $\mathbf{0 . 0 0 4 2}$ & $\mathbf{0 . 3 5 4 5 4}$ \\
Zinc & 13759.00 & 0.1687 & 0.13929 \\
HCH & 12204.00 & 0.3212 & 0.11833 \\
TOC & 13466.00 & 0.2923 & 0.12015 \\
Phosphorus & 18447.00 & 0.2128 & 0.12844 \\
Nitrogen & 16727.00 & 0.348 & 0.08715 \\
\hline
\end{tabular}

1999; Zwart et al., 2002) in the Elbe River was expected, but the detection of these organisms at the dumping site (ten months after the dumping activity) is an interesting finding of the present study, potentially indicating the establishment of bacterial communities originating from the dredged sediment at the dumping site. During dumping, the majority of the freshwater bacterial community is immediately dispersed together with the smaller sediment fractions of the dredged material. However, biofilm-forming bacteria on sand particles reach the dumping site and might integrate within the marine system. Although the different bacterial community compositions of the marine and freshwater environments has been well documented in a multitude of studies (Bowman and McCuaig, 2003; Miskin et al., 1999; Ravenschlag et al., 2001; Zwart et al., 2002), to the best of our knowledge, there is no valid information concerning which freshwater bacteria survive/adapt in the marine environment or coexist in both environments, with respect to entire bacterial communities. Previous results obtained using a ribosomal tag sequencing approach, considering the same samples, confirmed the results of the present study and emphasised that at least some freshwater bacteria (Rhizobiales, Hypomicrobium and Methylocystaceae or Burkholeriales and Hydrogenophilaceae) or, more precisely, the corresponding bacterial DNA molecules, are detectable at the dumping site at ten months after the dumping activity (unpublished data).

Transcriptomic approaches constitute a consequent next step to elucidate the activity of both the functionality of the entire community and the general activity of the freshwater types. Even if the functional inventory (DNA level) of the bacterial communities at the dumping site is significantly lower, the transcription of for instance pollutant specific genes might be enhanced instead. Environmental pollution, resulting from organic, heavy metal antibiotic contamination, was reported to influence gene regulation in previous studies (Baums et al., 2007; Busenlehner et al., 2003; Diaz and Prieto, 2000). While organic pollutants might be used as an alternative energy source (Gibson et al., 1988; Kanaly and Harayama, 2000), heavy metal contamination results in the up-regulation of transporter genes (Hu et al., 2005) or a chemical transformation of the substances, as in the case of mercury contamination (Nascimento and Chartone-Souza, 2003). The exposure to antibiotics has multiple effects, such as the expression of resistance genes or the utilisation of antibiotics as a nutrient source (Martinez, 2008). Metagenomic approaches, including the applied functional gene array and transcriptomics, represent current high-end technologies, offering new insights into complex microbial networks (Fuhrman, 2009). These technologies facilitate the assessment of complex systems, such as the phycosphere (Teeling et al., 2012), or the description of rare biospheres, such as deep-sea waters (Sogin et al., 2006). Novel insights, such as the detection of a lower functional diversity at a dumping site, deliver valuable information on the function of bacterial communities and might lead to the development of a functional gene array, as observed in recent years (He et al., 2007, 2010; Lu et al., 2012).

The results obtained in the present study demonstrated the tremendous complexity of bacterial community studies in the field.
However, considerable differences regarding the functional diversity of the bacterial community, comparing dumping and reference sites, were demonstrated. The bacterial community at the dumping site displayed a reduced functional gene inventory and the presence of typical freshwater phylotypes. In addition, the significant effect of DDX compounds on the functional structure, determined through DISTLM, indicated an influence of the dumping activity on the bacterial community.

These findings suggest that bacterial community analyses fulfil the basic criteria for ecological indicators (e.g., easily measurable and sensitive to environmental stress) in environmental monitoring programmes. However, further elaboration is needed for routine application. Thus, we strongly encourage additional bacterial community analyses and monitoring programmes for a better evaluation of anthropogenic stressors on the affected ecosystem.

\section{Acknowledgements}

This project was funded through the Hamburg Port Authority (HPA), Bundesanstalt für Gewässerkunde (BfG), Landesamt für Landwirtschaft, Umwelt und ländliche Räume des Landes Schleswig-Holstein (LLUR) and Nds. Landesbetrieb für Wasserwirtschaft, Küsten- und Naturschutz (NLWKN). The authors would like to thank the project partners for financial and data support and for critical discussion of the results of this study. The authors would also like to thank the reviewers for valuable comments to improve the original manuscript.

\section{Appendix A. Supplementary data}

Supplementary data associated with this article can be found, in the online version, at http://dx.doi.org/10.1016/j.marpolbul. 2013.10.022.

\section{References}

Adams, S.M., 2005. Assessing cause and effect of multiple stressors on marine systems. Marine Pollution Bulletin 51, 649-657.

Anderson, M., Gorley, R.N., Clarke, R.K., 2008. Permanova+ for Primer: Guide to Software and Statistical Methods.

Bartels, A., 2000. Internationale, regionale und nationale Regelungen zum Meeresschutz (Nord-, Ostsee und Atlantik), in: Landesamt für Natur und Umwelt des Landes Schleswig-Holstein, F. (Ed.). Landesamt für Natur und Umwelt des Landes Schleswig-Holstein, Flintbek, http://www.schleswigholstein.de, p. 29.

Baums, I., Goodwin, K., Kiesling, T., Wanless, D., Diaz, M., Fell, J., 2007. Luminex detection of fecal indicators in river samples, marine recreational water, and beach sand. Marine Pollution Bulletin 54, 521-536.

BfG, 1999. Handlungsanweisung für den Umgang mit Baggergut im Küstenbereich: (HABAK-WSV). Bundesanstalt für Gewässerkunde.

Bienhold, C., Boetius, A., Ramette, A., 2012. The energy-diversity relationship of complex bacterial communities in Arctic deep-sea sediments. ISME Journal 6, 724-732.

Bowman, J.P. McCuaig R.D., 2003. Biodiversity, community structural shifts, and biogeography of prokaryotes within Antarctic continental shelf sediment. Applied and Environment Microbiology 69, 2463-2483.

Busenlehner, L.S., Pennella, M.A., Giedroc, D.P., 2003. The SmtB/ArsR family of metalloregulatory transcriptional repressors: structural insights into prokaryotic metal resistance. FEMS Microbiology Reviews 27, 131-143.

Clarke, K., Gorley, R., 2006. PRIMER v6: User Manual/Tutorial. PRIMER-E, Plymouth, UK.

Dale, V.H., Beyeler, S.C., 2001. Challenges in the development and use of ecological indicators. Ecological Indicators 1, 3-10.

de Hoon, M., 2002. Cluster 3.0. Human Genom Center, University of Tokyo, Tokyo.

de Nijs, M.A.J., Winterwerp, J.C., Pietrzak, J.D., 2009. On harbour siltation in the fresh-salt water mixing region. Continental Shelf Research 29, 175-193.

Dean-Ross, D., Mills, A.L., 1989. Bacterial community structure and function along a heavy metal gradient. Applied and Environment Microbiology 55, 2002-2009.

Diaz, E., Prieto, M.A., 2000. Bacterial promoters triggering biodegradation of aromatic pollutants. Current Opinion in Biotechnology 11, 467-475.

dos Santos, H.F., Cury, J.C., do Carmo, F.L., dos Santos, A.L., Tiedje, J., van Elsas, J.D., Rosado, A.S., Peixoto, R.S., 2011. Mangrove Bacterial Diversity and the Impact of Oil Contamination Revealed by Pyrosequencing: Bacterial Proxies for Oil Pollution. Plos One 6. 
Eisen, M.B., Spellman, P.T., Brown, P.O., Botstein, D., 1999. Cluster analysis and display of genome-wide expression patterns (vol 95, pg 14863, 1998). Proceedings of the National academy of Sciences of the United States of America 96, 10943-10943.

Findlay, R.H., Trexler, M.B., Guckert, J.B., White, D.C., 1990. Laboratory study of disturbance in marine-sediments - response of a microbial community. Marine Ecology-Progress Series 62, 121-133.

Forstner, U., 1989. Contaminated sediments: lectures on environmental aspects of particle-associated chemicals in aquatic systems.

Fuhrman, J.A., 2009. Microbial community structure and its functional implications. Nature 459, 193-199.

Gibson, T.L., Abdul, A.S., Olsen, R.H., 1988. Microbial degradation of aromatic hydrocarbons in hydrogeologic material: microcosm studies. In: Proceedings of the Second National Outdoor Action Conference on Aquifer Restoration: Groundwater and Geophysical Methods, pp. 53-69.

Gillan, D.C., Danis, B., Pernet, P., Joly, G., Dubois, P., 2005. Structure of sedimentassociated microbial communities along a heavy-metal contamination gradient in the marine environment. Applied and Environment Microbiology 71, 679690.

Hazen, T.C., Dubinsky, E.A., DeSantis, T.Z., Andersen, G.L., Piceno, Y.M., Singh, N., Jansson, J.K., Probst, A., Borglin, S.E., Fortney, J.L., Stringfellow, W.T., Bill, M., Conrad, M.E., Tom, L.M., Chavarria, K.L., Alusi, T.R., Lamendella, R., Joyner, D.C., Spier, C., Baelum, J., Auer, M., Zemla, M.L., Chakraborty, R., Sonnenthal, E.L., D'Haeseleer, P., Holman, H.Y.N., Osman, S., Lu, Z.M., Van Nostrand, J.D., Deng, Y., Zhou, J.Z., Mason, O.U., 2010. Deep-sea oil plume enriches indigenous oildegrading bacteria. Science 330, 204-208.

He, Z.L., Deng, Y., Van Nostrand, J.D., Tu, Q.C., Xu, M.Y., Hemme, C.L., Li, X.Y., Wu, L.Y., Gentry, T.J., Yin, Y.F., Liebich, J., Hazen, T.C., Zhou, J.Z., 2010. GeoChip 3.0 as a high-throughput tool for analizing microbial community composition, structure and functional activity. ISME Journal 4, 1167-1179.

He, Z.L., Gentry, T.J., Schadt, C.W., Wu, L.Y., Liebich, J., Chong, S.C., Huang, Z.J., Wu, W.M., Gu, B.H., Jardine, P., Criddle, C., Zhou, J., 2007. GeoChip: a comprehensive microarray for investigating biogeochemical, ecological and environmental processes. ISME Journal 1, 67-77.

Hoon, M., Imoto, S., Miyano, S., 2002. Inferring gene regulatory networks from timeordered gene expression data using differential equations. In: Lange, S., Satoh, K., Smith, C. (Eds.), Discovery Science. Springer, Berlin Heidelberg, pp. 267-274.

Howarth, M.J., 2001. North sea circulation. In: John, H.S. (Ed.), Encyclopedia of Ocean Sciences. Academic Press, Oxford, pp. 1912-1921.

HPA, H.P.A., 2005. Umlagerung von Elbesediment nach Tonne E3 Bericht über Maßnahmen und Monitoring im Zeitraum August bis Oktober 2005. Hamburg Port Authority Hamburg, p. 31.

Hpa, H.P.A., 2009. Umgang mit Baggergut aus dem Hamburger Hafen Teilbericht Verbringung von Baggergut zur Tonne E3. Hamburg Port Authority HPA, Hamburg, p. 85.

Hu, P., Brodie, E.L., Suzuki, Y., McAdams, H.H., Andersen, G.L., 2005. Whole-genome transcriptional analysis of heavy metal stresses in Caulobacter crescentus. Journal of Bacteriology 187, 8437-8449.

IMO, 2000. London Convention 1972 Convention on the Prevention of Marine Pollution by Dumping of Wastes and Other Matter, 1972 Dredged material assesment framework, in: Organisation, I.M. (Ed.). International Maritime Organisation.

Jiang, D., Tang, C., Zhang, A., 2004. Cluster analysis for gene expression data: a survey. Knowledge and Data Engineering, IEEE Transactions 16, 1370-1386.

Kanaly, R.A., Harayama, S., 2000. Biodegradation of high-molecular-weight polycyclic aromatic hydrocarbons by bacteria. Journal of Bacteriology 182, 2059-2067.

Langston, W.J., Pope, N.D., 1995. Determinants of TBT adsorption and desorption in estuarine sediments. Marine Pollution Bulletin 31, 32-43.

Latimer, J.S., Davis, W.R., Keith, D.J., 1999. Mobilisation of PAHS and PCBs from inplace contaminated marine resuspension events. Estuarine, Coastal and Shelf Science 49, 577-595.

Liu, W.Z., Wang, A.J., Cheng, S.A., Logan, B.E., Yu, H., Deng, Y., Van Nostrand, J.D., Wu, L.Y., He, Z.L., Zhou, J.Z., 2010. Geochip-based functional gene analysis of anodophilic communities in microbial electrolysis cells under different operational modes. Environmental Science and Technology 44, 7729-7735.

Lu, Z.M., Deng, Y., Van Nostrand, J.D., He, Z.L., Voordeckers, J., Zhou, A.F., Lee, Y.J., Mason, O.U., Dubinsky, E.A., Chavarria, K.L., Tom, L.M., Fortney, J.L., Lamendella, R., Jansson, J.K., D’Haeseleer, P., Hazen, T.C., Zhou, J.Z., 2012. Microbial gene functions enriched in the Deepwater Horizon deep-sea oil plume. ISME Journal 6, 451-460.

Martinez, J.L., 2008. Antibiotics and antibiotic resistance genes in natural environments. Science 321, 365-367.

McLoughlin, L.C., 2000. Shaping Sydney Harbour: sedimentation, dredging and reclamation 1788-1990s (vol 31, pg 183, 2000). Australian Geographer 31, 271 271.

Miskin, I.P., Farrimond, P., Head, I.M., 1999. Identification of novel bacterial lineages as active members of microbial populations in a freshwater sediment using a rapid RNA extraction procedure and RT-PCR. Microbiology-UK 145, 1977-1987.

Nascimento, A.M., Chartone-Souza, E., 2003. Operon mer: bacterial resistance to mercury and potential for bioremediation of contaminated environments. Genetics and Molecular Research 2, 92-101.

Neufeld, J.D., Mohn, W.W., de Lorenzo, V., 2006. Composition of microbial communities in hexachlorocyclohexane $(\mathrm{HCH})$ contaminated soils from Spain revealed with a habitat-specific microarray. Environmental Microbiology 8, $126-140$.

Niemi, G., Wardrop, D., Brooks, R., Anderson, S., Brady, V., Paerl, H., Rakocinski, C., Brouwer, M., Levinson, B., McDonald, M., 2004. Rationale for a new generation of indicators for coastal waters. Environmental Health Perspectives 112, 979.

OSPAR, 2000. Quality Status Report 2000. OSPAR Commision 2000, London.

OSPAR, 2004. Revised OSPAR Guidelines for the Management of Dredged Material, in: THE, O.C.F.T.P.O.T.M.E.O., ATLANTIC, N.-E. (Eds.), http://www.dredging.org/ content.asp? page $=215$, p. 30 .

OSPAR, 2009. JAMP assessment of the environmental impact of dumping of wastes at sea, in: Convention, O. (Ed.), http://www.ospar.org.

Ravenschlag, K., Sahm, K., Amann, R., 2001. Quantitative molecular analysis of the microbial community in marine arctic sediments (Svalbard). Applied and Environment Microbiology, 387-395.

Sogin, M.L., Morrison, H.G., Huber, J.A., Mark Welch, D., Huse, S.M., Neal, P.R., Arrieta, J.M., Herndl, G.J., 2006. Microbial diversity in the deep sea and the underexplored "rare biosphere". Proceedings of the National academy of Sciences of the United States of America 103, 12115-12120.

Staneva, J., Stanev, E.V., Wolff, J.-O., Badewien, T.H., Reuter, R., Flemming, B., Bartholomä, A., Bolding, K., 2009. Hydrodynamics and sediment dynamics in the German Bight. A focus on observations and numerical modelling in the East Frisian Wadden Sea. Continental Shelf Research 29, 302-319.

Suarez-Suarez, A., Lopez-Lopez, A., Tovar-Sanchez, A., Yarza, P., Orfila, A., Terrados, J., Arnds, J., Marques, S., Niemann, H., Schmitt-Kopplin, P., Amann, R., RosselloMora, R., 2011. Response of sulfate-reducing bacteria to an artificial oil-spill in a coastal marine sediment. Environmental Microbiology 13, 1488-1499.

Sun, M.Y., Dafforn, K.A., Brown, M.V., Johnston, E.L., 2012. Bacterial communities are sensitive indicators of contaminant stress. Marine Pollution Bulletin 64, 1029 1038.

Tanner, P.A., Leong, L.S., Pan, S.M., 2000. Contamination of heavy metals in marine sediment cores from Victoria Harbour, Hong Kong. Marine Pollution Bulletin 40, 769-779.

Teeling, H., Fuchs, B.M., Becher, D., Klockow, C., Gardebrecht, A., Bennke, C.M., Kassabgy, M., Huang, S.X., Mann, A.J., Waldmann, J., Weber, M., Klindworth, A. Otto, A., Lange, J., Bernhardt, J., Reinsch, C., Hecker, M., Peplies, J., Bockelmann, F.D., Callies, U., Gerdts, G., Wichels, A., Wiltshire, K.H., Glockner, F.O., Schweder, T., Amann, R., 2012. Substrate-controlled succession of marine bacterioplankton populations induced by a phytoplankton bloom. Science 336, 608-611.

Van Nostrand, J.D., Wu, W.M., Wu, L.Y., Deng, Y., Carley, J., Carroll, S., He, Z.L., Gu, B.H., Luo, J., Criddle, C.S., Watson, D.B., Jardine, P.M., Marsh, T.L., Tiedje, J.M. Hazen, T.C., Zhou, J.Z., 2009. GeoChip-based analysis of functional microbia communities during the reoxidation of a bioreduced uranium-contaminated aquifer. Environmental Microbiology 11, 2611-2626.

Waldron, P.J., Wu, L.Y., Van Nostrand, J.D., Schadt, C.W., He, Z.L., Watson, D.B., Jardine, P.M., Palumbo, A.V., Hazen, T.C., Zhou, J.Z., 2009. Functional gene arraybased analysis of microbial community structure in groundwaters with a gradient of contaminant levels. Environmental Science and Technology 43, 3529-3534.

Wang, F.P., Zhou, H.Y., Meng, J., Peng, X.T., Jiang, L.J., Sun, P., Zhang, C.L., Van Nostrand, J.D., Deng, Y., He, Z.L., Wu, L.Y., Zhou, J.H., Xiao, X., 2009. GeoChipbased analysis of metabolic diversity of microbial communities at the Juan de Fuca Ridge hydrothermal vent. Proc. Natl. Acad. Sci. USA 106, 4840-4845.

Ward, B.B., Eveillard, D., Kirshtein, J.D., Nelson, J.D., Voytek, M.A., Jackson, G.A., 2007 Ammonia-oxidizing bacterial community composition in estuarine and oceanic environments assessed using a functional gene microarray. Environmental Microbiology 9, 2522-2538.

Wawrik, B., Mendivelso, M., Parisi, V.A., Suflita, J.M., Davidova, I.A., Marks, C.R. Nostrand, J.D., Liang, Y., Zhou, J., Huizinga, B.J., 2012. Field and laboratory studies on the bioconversion of coal to methane in the San Juan Basin. FEMS Microbiology Ecology 81, 26-42.

Wu, L., Kellogg, L., Devol, A.H., Tiedje, J.M., Zhou, J., 2008. Microarray-based characterzation of microbial community functional structure and heterogeneity in marine sediments from the gulf of Mexico. Applied and Environment Microbiology 74, 4516-4529.

Wu, L.Y., Liu, X., Schadt, C.W., Zhou, J.Z., 2006. Microarray-based analysis of subnanogram quantities of microbial community DNAs by using wholecommunity genome amplification. Applied and Environment Microbiology 72, 4931-4941.

Xie, J.P., He, Z.L., Liu, X.X., Liu, X.D., Van Nostrand, J.D., Deng, Y., Wu, L.Y., Zhou, J.Z., Qiu, G.Z., 2011. GeoChip-based analysis of the functional gene diversity and metabolic potential of microbial communities in acid mine drainage. Applied and Environment Microbiology 77, 991-999.

Yergeau, E., Kang, S., He, Z., Zhou, J., Kowalchuk, G.A., 2007. Functional microarray analysis of nitrogen and carbon cycling genes across an Antarctic latitudina transect. ISME Journal 1, 163-179.

Zhang, Z., Zhao, X., Liang, Y., Li, G., Zhou, J., 2013. Microbial functional genes reveal selection of microbial community by PAHs in polluted soils. Environmental Chemistry Letters $11,11-17$.

Zhou, J., 2003. Microarrays for bacterial detection and microbial community analysis. Current Opinion in Microbiology 6, 288-294.

Zwart, G., Crump, B.C., Agterveld, M., Hagen, F., Han, S.K., 2002. Typical freshwater bacteria: an analysis of available 16S rRNA gene sequences from plankton of lakes and rivers. Aquatic Microbial Ecology 28, 141-155. 